\title{
SVĚŘENSKÉ FONDY A PODÍLOVÉ FONDY: SPOLEČNÉ ZNAKY VE VZTAHU K MAJETKOVÉ PODSTATĚ A PRÁVŮM OPRÁVNĚNÝCH OSOB
}

\author{
JAKUB VOJTĚCH
}

\begin{abstract}
Trust Funds and Mutual Funds: Common Features in Relation to the Assets and Rights of Entitled Persons

Trust funds inspired by the Anglo-American trusts were implemented into Czech law by the back door through a mixed legal system in Québec and without linking this new legal institute with the legal regulation of mutual funds, even though precisely Anglo-American trusts are the foundation of mutual funds. Thus, the Czech legal theory rather compares trust funds to foundations or considers them to be quasi-legal persons. However, based on defining the main features of the Anglo-American trusts, a comparison of the legal position of the beneficiaries of trust funds and unit-holders in mutual funds may lead to interesting conclusions and similarities. The aim of the present paper is to look in more detail at the two parallel and independently existing Czech legal institutes and review the relationship of the entitled persons to the assets as well as the rights of the entitled persons to the performance from the assets.
\end{abstract}

Keywords: trust fund; mutual fund; beneficiary; unit-holder; profit participation certificates

Klíčová slova: svěřenský fond; podílový fond; obmyšlený; podílník; podílový list

DOI: $10.14712 / 23366478.2019 .19$

\section{1. ÚVOD*}

Je tomu již více než pět, co počínaje 1. lednem 2014 český právní řád uznává soukromoprávní institut podobný angloamerickým trusts a dává jej adresátům práva k dispozici. Právní úprava svěřenských fondů v občanském zákoníku (dále jen „,NOZ“ nebo „občanský zákoník“) a v zákoně o investičních společnostech a investičních fondech $^{2}$ (dále jen ,ZISIF“) nebyla (potažmo leckdy ani nemohla být) do českého práva vnesena se všemi souvisejícími angloamerickým instituty a důsledky.

\footnotetext{
* Tento text byl zpracován v rámci projektu studentského vědeckého výzkumu „Finance a informačni technologie jako hybatelé právní regulace v zemích Evropské unie a jejich trestněprávni aspekty" realizovaného v letech 2017-2019 na Právnické fakultě Univerzity Karlovy, SVV 260 360/2017.

1 Zákon č. 89/2012 Sb., občanský zákoník.

2 Zákon č. 240/2013 Sb., o investičních společnostech a investičních fondech.
} 
Inkorporace právního institutu na bázi trustu do českého práva byla do jisté míry spíše jen volnou inspirací zahraniční právní úpravou tzv. výslovných trustů (express trusts), a to navíc na pomezí angloamerického a kontinentálního právního systému (v podobě québecké fiducie/trustu). ${ }^{3}$ Svěřenské fondy jsou navíc oproti angloamerickým trusts zatíženy řadou formálních požadavků. Ty spočívají např. v povinnosti zakladatele vydat statut svěřenského fondu ve formě notářského zápisu ${ }^{4}$ nebo konstitutivním účinku zápisu svěřenského fondu do veřejného rejstř́ku. ${ }^{5}$ Atypickými prvky oproti common law jsou rovněž označení svěřenského fondu 6 nebo pojetí svěřenského fondu jako poplatníka daně z př́ijmů právnických osob, ${ }^{7}$ daně z nemovitých věcíi ${ }^{8}$ apod. ${ }^{9}$

Tyto odlišnosti a formální požadavky bývají nezř́idka kritizovány jako př́lišná odchylka od klasických trusts, která přinejmenším vede k oslabování smyslu tohoto právního institutu, př́padně jej de facto posunuje k právní úpravě právnických osob ${ }^{10}$ či prrímo k vytvoření kvaziprávnické osoby. ${ }^{11}$ Svěřenský fond ovšem právní osobnost nemá. Důsledkem je tudíž podle některých autorů určitý právní hybrid (připomínající fundaci bez právní osobnosti), ${ }^{12}$ který není osobou, ale ani věcí. ${ }^{13}$

Záměrem předkládaného textu je při př́ležitosti pěti let existence českého svěřenského práva poukázat na určitou blízkost mezi svěřenskými fondy a českému právu již dlouhou dobu známými podílovými fondy. Svěřenské fondy i podílové fondy totiž byly zakotveny v českém právu na sobě zcela nezávisle, byt’ jejich ideové základy jsou v podstatě identické. Podílové fondy vycházejí z angloamerických trusts a trust funds, svěřenské fondy pak byly převedeny do českého práva z common law „oklikou“ přes québecký smíšený právní systém a bez bližší návaznost na podílové fondy. Srovnání

3 JOSKOVÁ, L. - PĚSNA, L. Správa cizího majetku. Praha: Wolters Kluwer, 2017, s. 108; podobně též: SVEJKOVSKÝ, J. - MAREK, R. a kol. Správa ciziho majetku v novém občanském zákoníku. Komentár. § 1400-1474. Praha: C. H. Beck, 2015, s. 390; KOCÍ, M. Institut svěřenského fondu v NOZ. Bulletin advokacie, 2014, vol. 13, č. 1-2, s. 29 a násl.

$4 \S 1452$ odst. 1 a 3 NOZ.

$5 \S 1451$ odst. 2 NOZ.

$6 \$ 1450 \mathrm{NOZ}$.

7 § 17 odst. 1 písm. f) zákona č. 586/1992 Sb., o daních z př́jmů, ve znění pozdějších předpisů.

$8 \S 3$ odst. 2 písm. b) a $\S 8$ odst. 2 písm. b) zákona č. 338/1992 Sb., o dani z nemovitých věcí, ve znění pozdějších předpisů.

9 Pro účely DPH je dokonce výslovně stanoveno, že se na svěřenský fond hledí jako na právnickou osobu (viz § 4b odst. 2 zákona č. 235/2004 Sb., o dani z přidané hodnoty, ve znění pozdějších předpisů).

10 PIHERA, V. Krocení trustů. Svěřenské fondy v hledáčku první novely občanského zákoníku. Obchodněprávní revue, 2016, vol. 8, č. 5, s. 129-130; podobně též: HORN, K. Praktické aspekty svěřenského fondu ve světle návrhu urgentní novely občanského zákoníku. In: nkcr.cz [online]. 24. 2. 2015 [cit. 1. 12. 2018 ]. Dostupné na: https://www.nkcr.cz/casopis-ad-notam/detail/39_191-prakticke-aspekty-sverenskeho-fondu -ve-svetle-navrhu-urgentni-novely-obcanskeho-zakoniku.

11 JOSKOVÁ, L. - PĚSNA, L., c. d., s. 109, s. 134-135; podobně též: HOUFEK, I. Trusty v rekodifikaci soukromého práva. In: Bulletin advokacie [online]. 11. 6. 2013 [cit. 1. 12. 2018]. Dostupné na: http://www .bulletin-advokacie.cz/trusty-v-rekodifikaci-soukromeho-prava.

12 HOUFEK, I. Trusty v rekodifikaci soukromého práva [cit. 1. 12. 2018]; podobně též: PIHERA, Krocení trustů. Svěřenské fondy v hledáčku první novely občanského zákoníku, s. 129; SVEJKOVSKÝ, J. - MAREK, R. a kol., c. d., s. 390-391, s. 417-418; MIMROVÁ, T. Svěřenský fond jako efektivní nástroj ochrany majetku před věřiteli. Obchodněprávní revue, 2014, vol. 6, č. 3, s. 69, s. 74-75.

13 PIHERA, V. In: SPÁČIL, J. a kol. Občanský zákoník III. Věcná práva (\$ 976-1474). Komentár̆. Praha: C. H. Beck, 2013, s. 1191. Srov. dále též: HORN, K. Podrobněji k svěřenskému fondu. In: $n k c r . c z$ [online]. 19. 12. 2014 [cit. 1. 12. 2018]. Dostupné na: https://www.nkcr.cz/casopis-ad-notam/detail/39_181-podrobneji -k-sverenskemu-fondu. 
právní pozice oprávněných osob (tj. obmyšlených svěřenských fondů a podílníků podílových fondů), resp. nahlédnutí vztahu obmyšlených k majetkové podstatě svěřenského fondu a vymezení jejich práv na plnění z majetku svěřenského fondu právě prizmatem podílových fondů, může vést k zajímavým zjištěním a podobnostem.

\section{TRUSTOVÁ USPOŘÁDÁNÍ A JEJICH ZAKOTVENÍ V ČESKÉM PRÁVNÍM ŘÁDU}

\subsection{PĚT LET PRÁVNÍ ÚPRAVY SVĚŘENSKÝCH FONDŮ}

Česká právní úprava vymezuje svěřenské fondy jako právní institut soukromého práva v občanském zákoníku (v § 1448-1474 NOZ). Zde jsou svěřenské fondy jednou z podob správy cizího majetku (§ 1400-1474 NOZ), která je zařazena v hlavě druhé upravující věcná práva (§ 979-1474 NOZ). Tato hlava systematicky spadá do části třetí „Absolutní majetková práva“ (§ 976-1720 NOZ). Dále jsou svěřenské fondy jednou z možných právních forem fondů kvalifikovaných investorů dle ZISIF. ${ }^{14}$ Další provázanost mezi obecnou právní úpravou svěřenských fondů v NOZ a zvláštní úpravou svěřenských fondů v ZISIF je umožnění investičním společnostem stát se svěřenskými správci nejen investičního fondu s právní formou svěřenského fondu, ${ }^{15}$ ale i „obyčejného“ svěřenského fondu, který nepodléhá režimu ZISIF (tj. není investičním fondem). ${ }^{16}$

Převod struktury podobné trustu do českého práva se neobešel bez určité polemiky, pochybností či nejasností ohledně tohoto nového právního institutu. ${ }^{17}$ Ty byly do určité míry paradoxně podle některých názorů ${ }^{18}$ ještě akcentovány přijetím nedávné novely občanského zákoníku ${ }^{19}$. Jejím cílem byla totiž zejména úprava některých aspektů mladého svěřenského práva a zvláště pak minimalizace rizika možného zneužívání institutu svěřenského fondu pro praní špinavých peněž, a to zakotvením evidence svěřenských fondů s deanonymizací totožnosti hlavních subjektů svěřenských fondů (zakladatele, svěřenského správce a obmyšleného). ${ }^{20}$

$14 \S 95$ odst. 1 písm. c) ZISIF ve spojení s $§ 101$ odst. 1 písm. b) a $§ 148$ a násl. ZISIF.

$15 \S 150$ odst. 1 a 2 ZISIF.

$16 \S 11$ odst. 6 písm. a) a $§ 151$ ZISIF.

17 Srov. např.: JOSKOVÂ, L. - PĚSNA, L., c. d., s. 114; PIHERA, Krocení trustů. Svěřenské fondy v hledáčku první novely občanského zákoníku, s. 129; KOCÍ, c. d., s. 32.

18 Srov. PIHERA, V. Krocení trustů. Svěřenské fondy v hledáčku první novely občanského zákoníku, c. d., s. 129 a násl.; HORN, K. Praktické aspekty svěřenského fondu ve světle návrhu urgentní novely občanského zákoníku [cit. 1. 12. 2018].

19 Zákon č. 460/2016 Sb., kterým se mění zákon č. 89/2012 Sb., občanský zákoník, a další související zákony.

20 Sněmovní tisk 642. Vládní návrh zákona, kterým se mění zákon č. 89/2012 Sb., občanský zákoník, a další související zákony. Poslanecká sněmovna Parlamentu České republiky. 8. volební období. In: $p s p$ .$c z$ [online]. 2018, s. 16-19, s. 27-31 [cit. 1. 12. 2018]. Dostupné na: http://www.psp.cz/sqw/text/orig2 .sqw?idd $=122333$. 
Svěřenské fondy nejsou co do výsledku i do inspirační předlohy čistým pojetím klasických angloamerických trusts, ale adaptací českému právnímu řádu, která navíc sama vychází z právního řádu smíšeného typu (quebeckého občanského zákoníku). Hlavní znaky trustu a trustových struktur jsou nicméně př́tomny i v českém pojetí tohoto právního institutu. Přitom lze vycházet z toho, že základní podstatou trustu je:

a) v zásadě tř́ístranné schéma osob (settlor-trustee-beneficiary); 21

b) separace (oddělení/vyčlenění) přesně vymezeného majetku, který byl doposud ve vlastnictví nějaké osoby (zakladatele) ${ }^{22}$ inter vivos nebo mortis causa ${ }^{23}$ za stanoveným konkrétním účelem ${ }^{24}$ (zejména ve prospěch určité osoby - beneficienta);

c) osobní povinnost správce spravovat svěřený majetek za stanoveným účelem, kdy ve vztahu $\mathrm{k}$ beneficientovi jde o povinnost fiduciární povahy, ${ }^{25}$ a na druhé straně vybavení beneficienta určitými právy vůči tomuto správci; 26

d) prolínání absolutních (věcněprávních) a relativněprávních (osobních) prvkư ${ }^{27}$ týkajících se vyčleněného majetku a jeho správy, ${ }^{28}$ kdy struktura práv a povinností $\mathrm{k}$ vyčleněnému majetku a jeho správě se nevyznačuje právní osobností (nevede k založení samostatného právního subjektu). ${ }^{29}$

V souvislosti se zakotvením svěřenských fondů v českém právu a hlavním předmětem zájmu tohoto textu je patrně nejmarkantnější absence děleného vlastnictvíi ${ }^{30}$ - nebo spíše vlastnických titulů 31 - a rozlišování mezi legal ownership, tedy „právním“32 či „formálním“33 vlastnictvím, a beneficial ownership neboli „beneficiálním“ či „ekonomickým“34 vlastnictvím v českém právu. Toto duální pojetí vlastnictví v common law systémech se při vytvoření trustu projevuje „rozštěpením“35 původního celistvého vlastnického práva settlora (,zakladatele“) při převodu majetku určité osobě (trusteemu neboli „,správci“), které důvěruje, ${ }^{36}$ a to ke správě ve prospěch (benefit) jiného (beneficiary čili „,beneficienta“). ${ }^{37}$ Vznikem trustu je totiž (i) formální legal title („právní titul“" $)^{38}$ dle common law převeden na trusteeho, který se tak stává formálním common

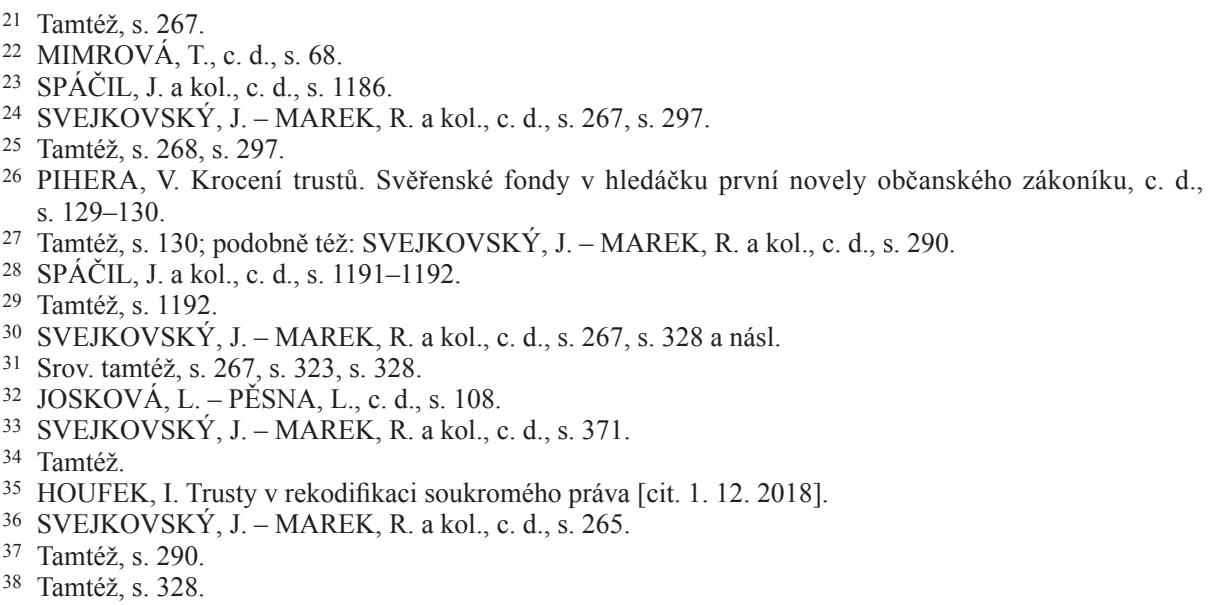


law vlastníkem, a (ii) ekvitní beneficial interest či equitable title („,spravedlivý titul“) $)^{39}$ podle práva equity na beneficiary, ${ }^{40}$ jenž se stane vlastníkem ekvitním a jemuž náleží oprávnění z majetku trustu (vlastnický podíl k majetku trustu podle equity).

Beneficiary angloamerického trustu nenáleží jen práva in personam vůči trusteemu (požadovat řádné plnění povinností a respektování nároku beneficiary), ale v zásadě obecně vůči jakémukoliv dalšímu formálnímu vlastníkovi dle common law. ${ }^{41}$ Kromě toho má beneficiary rovněž práva vztahující se k samotnému majetku trustu (right in the trust), a to at' jde o původní majetek trustu, nebo majetek nově pořízený za majetek původní, kdy všichni beneficiaries tvoří $100 \%$ oprávněných držitelů titulu podle equity (equitable interest). ${ }^{42}$

\subsection{PODÍLOVÉ FONDY JAKO VÝRAZ TRUSTU}

Dlouhou dobu před přijetím právní úpravy svěřenských fondů znalo české právo podílové fondy. ${ }^{43}$ Podílové fondy jsou svou povahou vlastně trusty sui generis ${ }^{44}$ a jako zvláštní soubor majetku a práv podílníků bez právní osobnosti mají zřejmě nejblíže k myšlence správy majetku cizí osobou, tradičním angloamerickým trusts a zvláště pak tzv. unit trusts. ${ }^{45}$ Unit trust je totiž svou podstatou tradiční trust, jehož majetek (resp. beneficiální oprávnění z něj plynoucí) je rozdělen na ideální abstraktní podíly (jednotky neboli units) ve vlastnictví oprávněných osob (majitelů těchto jednotek). ${ }^{46}$ Unit trusts jsou tedy založeny na ekvitním spoluvlastnickém právu investorů - vlastníků poměrných ideálních podílů, přičemž např. unijní právní úprava je právě řadí mezi podílové fondy. ${ }^{47}$

Hlavní rozdíl mezi unit trusts a klasickými podílovými fondy spočívá v tom, že si unit trusts ponechávají hlavní znak angloamerických trustů, tedy že trustee je common law vlastníkem majetkové podstaty. Samotný výkon správy nicméně vykonává správce (manažerská společnost), na nějž trustee dohlíží. ${ }^{48} \mathrm{Na}$ druhou stranu je významným

39 SVEJKOVSKÝ, J. - MAREK, R. a kol., c. d., s. 265, s. 328; stejně též: MIMROVÁ, T., c. d., s. 70.

40 PIHERA, V. Trust. Vybrané aspekty. Obchodněprávní revue, 2009, vol. 1, č. 7, s. 196.

41 SVEJKOVSKÝ, J. - MAREK, R. a kol., c. d., s. 280-281, s. 293.

42 Tamtéž, s. 280-281, s. 293, s. 361-362.

43 Před rekodifikací soukromého práva byla právní úprava podílových fondů obsažena v $§ 6$ a násl. zákona č. 189/2004 Sb., o kolektivním investování, ve znění pozdějších předpisů. Dnes jsou podílové fondy vymezeny $\mathrm{v} \S 102$ a násl. ZISIF.

44 HORN, K. Praktické aspekty svěřenského fondu ve světle návrhu urgentní novely občanského zákoníku [cit. 1. 12. 2018].

45 HOUFEK, I. Trusty a společnosti s variabilním kapitálem. In: is.cuni.cz [online]. Praha, 2012, s. 105 [cit. 1. 12. 2018]. Disertační práce. Univerzita Karlova, Právnická fakulta, Katedra obchodního práva. Vedoucí práce Stanislava Černá. Dostupné na: https://is.cuni.cz/webapps/zzp/download/140019524/?lang=en.

46 Tamtéž, s. 82-83.

47 Viz čl. 1 odst. 3 směrnice Evropského parlamentu a Rady 2009/65/ES ze dne 13. července 2009 o koordinaci právních a správních předpisů týkajících se subjektů kolektivního investování do převoditelných cenných papírů (SKIPCP), v němž je stanoveno, že ,subjekty uvedené v odstavci 2 mohou být zřizovány podle smluvního práva (jako podilové fondy spravované správcovskou společností) nebo podle trustového práva (jako ,unit trusts') nebo podle práva společností (jako investiční společnosti). Pro účely této směrnice a) se ,podilovými fondy ' rozumí rovněž ,unit trusts ‘“

48 HOUFEK, I. Trusty a společnosti s variabilním kapitálem, s. 84 [cit. 1. 12. 2018]. 
odlišujícím znakem unit trusts ve srovnání s trusty převoditelnost jednotek, tedy ekvitních pozic beneficientů (podílníků). ${ }^{49}$ Tentýž prvek (převoditelnost majetkových práv beneficientů) je východiskem právní úpravy podílových fondů. Jeho výrazem jsou cenné papíry zvané podílové listy.

\section{ZÁKLADNÍ CHARAKTERISTIKA SVĚŘENSKÉHO FONDU VE VZTAHU K JEHO MAJETKOVÉ PODSTATĚ}

Vznikem svěřenského fondu (v zásadě zápisem do evidence svěřenských fondů ${ }^{50}$ ) vzniká „oddělené a nezávislé vlastnictví vyčleněného majetku“, ${ }^{51} \mathrm{k}$ němuž vykonává vlastnická práva na účet svěřenského fondu svým jménem svěřenský správce. ${ }^{52}$ Jedná se však o pouhý výkon vlastnických práv v rozsahu plné správy ${ }^{53}$ majetku ve svěřenském fondu, přestože je svěřenský správce formálně zapisován ve veřejných seznamech jako vlastník majetku ve svěřenském fondu (ovšem právě s poznámkou „svěřenský správce“). ${ }^{54}$

\subsection{MAJETEK SVĚŘENSKÉHO FONDU: VLASTNICTVÍ BEZ VLASTNÍKA}

Na první pohled není formulace „oddělené a nezávislé vlastnictví vyčleněného majetku" z teoretického hlediska a koherence občanského zákoníku zcela vhodná. Pojem „oddělené“ vlastnictví majetku je totiž třeba vykládat tak, že je odděleno od majetku jiných osob (zakladatele i správce). Výraz „nezávisléc potom znamená, že není vztahováno vůbec $k$ žádné osobě. ${ }^{55}$ Jak pojem vlastnictví, tak výraz majetek ovšem $\mathrm{NOZ}$ na jiných místech definuje vždy ve vztahu k určité osobě. Pojmově si nelze na základě jiných ustanovení občanského zákoníku představit majetek (,souhrn všeho, co osobě

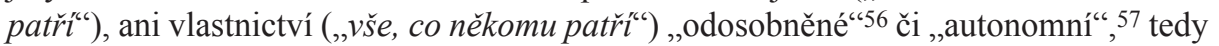
bez souvztažnosti k určité fyzické nebo právnické osobě. ${ }^{58}$ Ostatně lze argumentovat rovněž tím, že existence nejen vlastnického práva, ale jakéhokoliv subjektivního práva (oprávnění) bez konkrétní osoby, které by toto právo náleželo, je rozporem samo o sobě (contradictio in adiecto), jenž vyvolává značné teoretické otazníky. ${ }^{59}$

49 Tamtéž, s. 90, s. 92.

50 Srov. $\$ 1451$ odst. 2 a 3 NOZ.

$51 \S 1448$ odst. 2 NOZ.

$52 \S 1448$ odst. $3 \mathrm{NOZ}$.

$53 \S 1456 \mathrm{NOZ}$.

54 Tamtéž.

55 SVEJKOVSKÝ, J. - MAREK, R. a kol., c. d., s. 402.

56 Srov. tamtéž, s. 336.

57 SPÁČIL, J. a kol., c. d., s. 1192.

58 Viz vymezení majetku a jmění ( $\$ 495 \mathrm{NOZ}$ : „Souhrn všeho, co osobě patři, tvoři její majetek. Jmění osoby tvoři souhrn jejího majetku a jejich dluhü."), stejně jako vlastnictví v občanském zákoníku (§ 1011 NOZ: „V̌se, co někomu patří, všechny jeho věci hmotné i nehmotné, je jeho vlastnictvím.").

59 SVEJKOVSKÝ, J. - MAREK, R. a kol., c. d., s. 352 a násl.; srov. též: KNAPP, V. Teorie práva. Praha: C. H. Beck, 1995, s. 193 a násl. 
Česká právní úprava přesto bez ohledu na soudržnost právního řádu (či přinejmenším civilního práva) poměrně nedůsledně ${ }^{0}$ prolamuje princip přiřazování majetku a vlastnictví61 (či obecně práv) k osobám. Majetek vyčleněný do svěřenského fondu totiž i dle výslovného zákonného ustanovení nenáleží ani zakladateli, ani svěřenskému správci, ani osobě, které má být ze svěřenského fondu plněno (obmyšlenému). ${ }^{62}$ U tohoto právního institutu je tak ad hoc vytvořen umělý konstrukt spočívající v tom, že vyčleněný majetek nepatř́ žádnému ze třech hlavních subjektů, jejichž vztahy jsou základem svěřenského fondu, resp. nenáleží ani samotnému svěřenskému fondu, ani nejde o res nullius. ${ }^{63}$

V tomto smyslu lze proto hovořit o majetku nevztaženém $\mathrm{k}$ určité osobě vlastníka, nýbrž specifikovaném právě vyčleněním k určitému účelu, čímž ho lze označit za majetek ,odvlastněný“ ${ }^{64}$ jenž je ,přrivlastněn ve prospěch určitého účelu“ “ ${ }^{65}$ Majetek totiž zakladatel vyčleňuje do svěřenského fondu a svěřje jej svěřenskému správci za určitým účelem. ${ }^{66}$ Tento majetek je tedy „vyčleněn $\mathrm{k}$ určitému účelu“ a nemaje žádného vlastníka (jde o „oddělené a nezávislé vlastnictví vyčleněného majetku“) v podstatě doslova „přivlastněn“ (k) účelu svěřenského fondu. ${ }^{67}$ Účel vyčlenění majetku z vlastnictví zakladatele se promítá i do účelu samotného svěřenského fondu. Ten může být obecně bud' veřejně prospěšný, nebo soukromý ${ }^{68}$ (sloužící prospěchu určité osoby, včetně investování s rozdělením zisku určeným osobám). ${ }^{69}$ Tomuto účelu musí odpovídat i označení svěřenského fondu. ${ }^{70}$

Samotný zakladatel je toliko původním vlastníkem majetku vyčleněného do svěřenského fondu, který své vlastnické právo ztrácí okamžikem vzniku svěřenského fondu. ${ }^{71}$ Svěřenský správce $\mathrm{k}$ vyčleněnému majetku vlastnická práva pouze vykonává (tedy není jejich primárním subjektem) a tento výkon je navíc omezen přinejmenším zákonem a smyslem správy majetku ve svěřenském fondu (tedy správy majetku za určitým účelem, nejčastěji ve prospěch jiných osob, navíc patrně s nemožností tento majetek např́ opustit, zničit apod. ${ }^{72}$ ), prŕípadně též statutem svěřenského fondu nebo smlouvou se zakladatelem tohoto fondu.

Ani obmyšlenému vlastnické právo nesvědčí, nebot' (kromě toho, že mohou existovat svěřenské fondy i bez této osoby ${ }^{73}$ ) mu náleží pouze určité (ekonomické) výhody

${ }^{60} \mathrm{~V}$ québeckém občanském zákoníku byly přinejmenším právě prvky majetku bez osoby vlastníka a vlastnického práva nevztaženého $k$ určité osobě promítnuty i do obecné úpravy a definice těchto institutů (bliže viz SVEJKOVSKÝ, J. - MAREK, R. a kol., c. d., s. 357).

61 SPÁČIL, J. a kol., c. d., s. 1192.

$62 \S 1448$ odst. 3 NOZ.

63 JOSKOVÁ, L. - PĚSNA, L., c. d., s. 110, s. 130.

64 SVEJKOVSKÝ, J. - MAREK, R. a kol., c. d., s. 336-337, s. 394.

65 Tamtéž, s. 336-337, s. 458 (srov. též s. 401).

$66 § 1448$ odst. 1 NOZ.

67 SVEJKOVSKÝ, J. - MAREK, R. a kol., c. d., s. 331, s. 336, s. 394.

$68 § 1449$ odst. $1 \mathrm{NOZ}$.

$69 \S 1449$ odst. 2 NOZ.

$70 \S 1450$ odst. 2 NOZ.

71 JOSKOVÁ, L. - PĚSNA, L., c. d., s. 110.

72 Tamtéž, s. 110.

73 Tamtéž, s. 110-111, s. 126, s. 139. Srov. též jednu z obsahových náležitostí statutu svěřenských fondů v § 1452 odst. 2 písm. f), kde se stanoví, že ,má-li být ze svěrenského fondu plněno určité osobě jako obmyšlenému $[\ldots]^{“}$. 
plynoucí ze správy majetku ve svěřenském fondu ${ }^{74} \mathrm{v}$ podobě práva požadovat plnění, které mu bylo přiznáno ${ }^{75}$. Pokud jde o vlastnění majetku samotným svěřenským fondem, je nutno poukázat na to, že svěřenský fond nemá právní osobnost, a tudíž nemůže mít práva ani povinnosti. ${ }^{76}$

Konečně pak označení majetku ve svěřenském fondu za res nullius by bylo proti veškeré logice a smyslu tohoto právního institutu. Ve vztahu k majetku svěřenského fondu dochází $\mathrm{k} v y ́ k o n u$ vlastnických práv ze strany svěřenského správce a kromě toho svěřenský fond jako takový není věcíi7 (res).

Vytvořením samostatně stojícího majetku bez vlastníka tak byl v českém právu podle québeckého vzoru ${ }^{78}$ „,vyřešen“ problém neexistujících dělených vlastnických titulů, tedy dualita mezi formálním common law vlastnickým právem (legal title převáděný na trusteeho zakladatelem trustu) a ekvitním vlastnickým právem (equitable title náležející beneficiary) $\mathrm{k}$ témuž předmětu vlastnického práva. ${ }^{79}$ Zatímco $\mathrm{v}$ angloamerickém trustu dochází k určitému vlastnickému dualismu (kdy trustee, jemuž se blíží tuzemský svěrenský správce, získává legal title, a beneficiary, ke kterému lze připodobnit českého obmyšleného, disponuje beneficiary interest / equitable title), česká právní úprava vychází z toho, že svěřenský správce pouze vlastnická práva vykonává, ale není subjektem těchto práv. Zakladatel nepřevádí svěřenskému správci vlastnické právo, ale majetek vyčleňuje do autonomního jmění. ${ }^{80}$ Zařazení institutu svěřenského fondu právě do části NOZ pojednávající o správě cizího majetku je tak z tohoto pohledu odůvodněné. Trustee angloamerického trustu však není ani tak správcem, jakožto v prvé řadě právě formálním vlastníkem majetkové podstaty trustu (a dále vykonavatelem vůle zakladatele trustu).

\subsection{SROVNÁNÍ S PODÍLOVÝMI FONDY}

Podnětné je v otázce (ne)určení subjektu vlastnického práva k majetku svěřenského fondu srovnání právní úpravy svěřenského fondu a podílového fondu. Svěřenský fond ani podílový fond sice právní osobnost nemají, problém vlastnického práva $\mathrm{k}$ majetkové podstatě podílového fondu ovšem řeší ZISIF tak, že formálně „vlastnické právo $k$ majetku v podilovém fondu náleži společně všem podílníkům, a to v poměru podle hodnoty jimi vlastněných podilových listư“ ${ }^{\circ 1} \mathrm{Z}$ tohoto zajímavého srovnání dále vyplývá, že zatímco svěřenský fond je „odděleným a nezávislým vlastnictví vyčleněného majetku“, 82 podílový fond je tvořen jměním ${ }^{83}$ zahrnujícím jak majetek, tak dlu-

74 JOSKOVÁ, L. - PĚSNA, L., c. d., s. 110-111.

$75 \S 1457-\S 1459$ NOZ.

76 JOSKOVÁ, L. - PĚSNA, L., c. d., s. 110. V tomto ohledu bude zejména relevantní § 17 odst. 2 NOZ, v němž je stanoveno: „Zř́dí-li někdo právo nebo uloži-li povinnost tomu, co osobou není, přičte se právo nebo povinnost osobě, které podle povahy právního př́padu náleží."

77 SPÁĆIL, J. a kol., c. d., s. 1186.

78 JOSKOVÁ, L. - PĚSNA, L., c. d., s. 108; srov. též: SVEJKOVSKÝ, J. - MAREK, R. a kol., c. d., s. 329-330, s. 336-337; HORN, K. Podrobněji k svěřenskému fondu [cit. 1. 12. 2018].

79 HOUFEK, I. Trusty v rekodifikaci soukromého práva [cit. 1. 12. 2018].

80 Srov. SVEJKOVSKÝ, J. - MAREK, R. a kol., c. d., s. 338.

$81 \S 102$ odst. 1 ZISIF.

$82 \S 1448$ odst. 2 NOZ.

83 Tamtéž. 
hy. ${ }^{84}$ Nicméně podílníci mají právo $\mathrm{k}$ poměrné hodnotě majetku v podílovém fondu. Dluhy v podílovém fondu nejsou odpovědností podílníků ${ }^{85}$ a je nutno je uspokojovat $\mathrm{z}$ majetku $\mathrm{v}$ tomto podílovém fondu. ${ }^{86}$

Co však na první pohled sbližuje právní úpravu podílových fondů a svěřenských fondů, je postavení jejich ,správců“. Dle ZISIF totiž „vlastnická práva k majetku v podílovém fondu vykonává vlastním jménem a na účet podílového fondu jeho obhospodařovatel“ ${ }^{87}$ Jde v podstatě o tutéž formulaci, jaká je uvedena u určení výkonu vlastnických práv svěřenským správcem v NOZ. ${ }^{88}$ Jak u svěřenského fondu, tak podílového fondu tedy jde o pouhý výkon vlastnických práv (svěřenským správcem, resp. obhospodařovatelem), čímž lze vlastně rozumět správu majetku v daném fondu.

Přestože podílníci formálně mají vlastnické právo $\mathrm{k}$ majetku v podílovém fondu, nemohou jakkoliv disponovat s tímto majetkem. Ostatně na právní postavení podílníků se neuplatní ustanovení NOZ o spoluvlastnictví, ani nemůže žádný z nich požadovat oddělení majetku v podílovém fondu, rozdělení podílového fondu nebo zrušení podílového fondu. ${ }^{89}$ Podílníkům tedy podobně jako angloamerickým beneficiaries plynou pouze určité ekonomické výhody z vlastnictví (fakticky jde spíše o kvazivlastnictví) majetku v podílovém fondu, které je navíc po vzoru unit trusts vyjádřeno v podobě určitých podílů (představovaných podílovými listy).

\section{PRÁVO OBMYŠLENÉHO NA PLNĚNÍ ZE SVĚǨENSKÉHO FONDU}

Tím se dostáváme ke klíčové postavě právní úpravy svěřenských fondů, a to obmyšlenému. Občanský zákoník jej na několika místech označuje jako „osobu, které má být ze svěrenského fondu plněno".90 Jde o subjekt, jehož prospěch (výhoda) může být jedním $z$ důvodů vytvoření svěřenského fondu a účelem svěřenského fondu. ${ }^{91}$

Obmyšlený má právo na určité ,plnění ze svěřenského fondu“.92 Toto plnění občanský zákoník blíže vyděluje do těchto základních okruhů: (a) právo na plody nebo užitky ze svěřenského fondu, (b) právo na majetek ze svěřenského fondu, případně (c) právo na podíly na nich. ${ }^{93}$ Podmínky na plnění (napřr. určení času, místa, rozsahu plnění apod.) ze svěřenského fondu by měl určovat statut svěřenského fondu. ${ }^{94} \mathrm{~V}$ souladu se statutem má také obmyšlený právo požadovat za trvání svěřenského fondu př́ílušné plnění. ${ }^{95}$

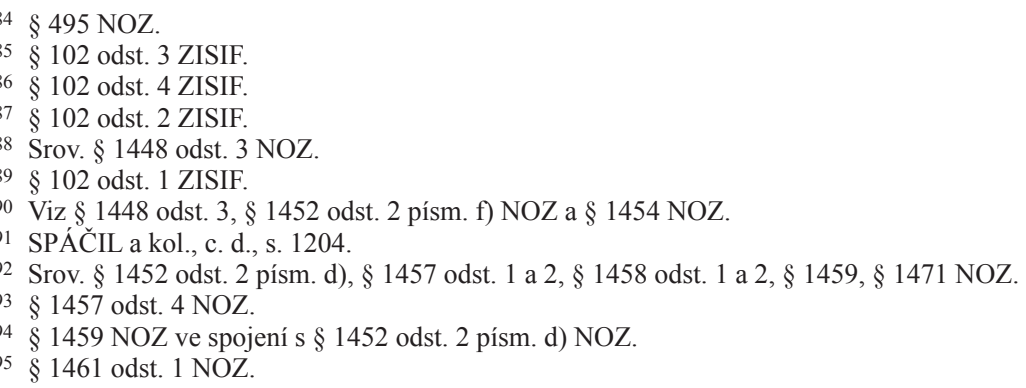




\subsection{IUS FRUENDI A IUS ADQUIRENDI}

Kategorii plodů přirozených (fructus naturales) a užitků, tj. plodů právních (fructus civiles), právní teorie souhrnně označuje jako „výnosy““ 96 Právo na plody a užitky tedy vyjadřuje oprávnění k výnosové složce majetku svěřenského fondu (během doby svěřenské správy ${ }^{97}$ ) neboli právo získávat plody a užitky z majetku svěřenského fondu. Toto právo je možné pojmenovat jako ius fruendi. ${ }^{98}$

Druhé oprávnění obmyšleného je možné označit jako ius adquirendi ${ }^{99}$ a spočívá v právu obmyšleného na nabytí „kmenového majetku“" ${ }^{100}$ svěřenského fondu nebo jeho části, tj. jedná se o právo na vydání (celé či části, tj. podílu) spravované majetkové podstaty ${ }^{101}$ ze svěřenského fondu do plného vlastnictví obmyšleného. Po mezidobí „,bezvlastnické“ správy svěřenským správcem tedy majetek svěřenského fondu opětovně získá vlastníka. Ius adquirendi nelze podle mého názoru ztotožnit s beneficial interest ve smyslu ekonomického oprávnění k majetkové podstatě (majetku svěřenského fondu), ${ }^{102}$ tedy neodpovídá right in the trust. Na obmyšlené, kterým svědčí právo na majetek ze svěřenského fondu, je nanejvýš možné nahlížet jako na faktické (spolu) vlastníky in spe.

\subsection{SROVNÁNÍ S PODÍLOVÝMI FONDY}

Pro vymezení postavení podílníků a jejich práv hraje klíčovou úlohu podílový list. Tyto cenné papíry představují podíl podílníka na podílovém fondu, ${ }^{103}$ přičemž podílníci mají ,vlastnické právo k majetku v podílovém fondu [...], a to v poméru podle hodnoty jimi vlastněných podílových listư‘ ${ }^{104}$ ZISIF dále rozvádí pojem podílového listu jako „,cenn[ého] papír[u] [...], se kterým jsou spojena práva podílníka plynoucí $z$ tohoto zákona nebo ze statutu podílového fondu“. ${ }^{105}$ Podílový list je proto cenný papír nebo zaknihovaný cenný papír, který má dvě základní charakteristiky: (i) představuje podíl podílníka na podílovém fondu a (ii) jsou s ním spojena práva, která stanoví zákon nebo statut podílového fondu.

Pokud jde o samotná práva na plnění z majetku podílového fondu, která jsou spojena s podílovým listem, ZISIF obsahuje jejich demonstrativní výčet. Mezi tato oprávnění je možné řadit právo na: (a) rozdílný, pevný nebo podřízený podíl na zisku nebo na likvi-

\footnotetext{
${ }^{96}$ LAVICKÝ, P. a kol. Občanský zákoník I. Obecná část (§ 1-654). Komentář. Praha: C. H. Beck, 2014, S. 1738.

97 SPÁČIL, J. a kol., c. d., s. 1208.

98 Srov. k tomu: KINCL, J. - URFUS, V. - SKŘEJPEK, M. Řimské právo. Praha: C. H. Beck, 1995, s. 154, s. 195.

${ }^{99}$ Odvozenina od latinského infinitivu adquīrere ve významu „,nabýt“, „získat“ (srov. Adquirere. In: en .wiktionary.org [online]. [cit. 1. 12. 2018]. Dostupné na: https://en.wiktionary.org/wiki/adquirere\#Latin).

100 SPÁČIL, J. a kol., c. d., s. 1208.

${ }^{101}$ Důvodová zpráva k občanskému zákoníku. In: obcanskyzakonik.justice.cz [online], s. 354 [cit. 1. 12. 2018 ]. Dostupné na: http://obcanskyzakonik.justice.cz/images/pdf/Duvodova-zprava-NOZ-konsolidovana -verze.pdf.

102 Srov. podobně: SVEJKOVSKÝ, J. - MAREK, R. a kol., c. d., s. 466-467.

$103 \S 115$ ZISIF.

$104 \S 102$ odst. 1 ZISIF.

$105 \S 115$ ZISIF.
} 
dačním zůstatku, (b) vyplacení zálohy na zisk, (c) nižší úplatu účtovanou v př́ípadě, že výkonnost podílového fondu přesáhne určený ukazatel (benchmark), s nímž je výkonnost srovnávána, nebo (d) nižší srážku za odkoupení, je-li s podílovým listem spojeno právo na jeho odkoupení. ${ }^{106}$ Pokud by byla s podílovými listy spojena stejná práva, takové podílové listy tvoří jeden druh. ${ }^{107}$ ZISIF dále umožňuje přiznat vlastníkům podílových listů tzv. zvláštní práva vymezená statutem podílového fondu. ${ }^{108}$

ZISIF tedy výslovně jako jedno z možných práv podílníka stanoví právo na rozdílný, pevný nebo podřizený podíl na zisku nebo na likvidačním zůstatku. Při bližším zkoumání tato oprávnění do značné míry připomínají právě práva na plnění obmyšlenému v podobě (a) ius fruendi (ziskem lze totiž rozumět určitý výnos) ${ }^{109}$ a (b) ius adquirendi (likvidační zůstatek odpovídá zpeněženému majetku po odečtení dluhů při likvidaci podílového fondu, tj. bez vydání majetku jako takového ${ }^{110}$ podílníkům ${ }^{111}$ ). Při zrušení podílového fondu s likvidací (po uplynutí doby trvání podílového fondu nebo z jiného důvodu ${ }^{112}$ ) totiž obhospodařovatel zpeněží fondový majetek (např. prodejem třetí osobě) a splní dluhy. ${ }^{113}$ Administrátor podílového fondu posléze vyplatí podílníkům jejich podíly na likvidačním zůstatku. ${ }^{114}$

\section{VZTAH OBMYŠLENÉHO K MAJETKOVÉ PODSTATĚ SVĚŘENSKÉHO FONDU}

\subsection{POUZE IUS FRUENDI A IUS ADQUIRENDI Z MAJETKU SVĚŘENSKÉHO FONDU}

Z výše uvedeného vyplývá, že obmyšlený českého svěřenského fondu nemá žádný přímý kvalifikovaný vztah (přímé majetkové právo) k majetkové podstatě svěřenského fondu (majetku ve svěřenském fondu). ${ }^{115} \mathrm{~V}$ žádném př́padě pak nemá obmyšlený českého svěřenského fondu dle výslovného znění zákona k majetkové podstatě vlastnické právo, a to ani v čistě formálním smyslu, tedy blížícím se postavení podílníků podílových fondů v českém právu. To lze vyvodit i ze zákonné úpravy, dle níž mu je

\footnotetext{
$106 \S 120$ odst. 2 ZISIF.

$107 \S 120$ odst. 1 ZISIF.

108 § 121 odst. 1 ZISIF.

109 V této souvislosti je zajímavé si povšimnout, že občanský zákoník dává výslovně slovo zisk do souvislosti se svěřenským fondem formulací, dle níž svěřenský fond „lze zř́dit i za účelem investování pro dosažení zisku“ (§ 1449 odst. 2 NOZ). Výraz zisk se rovněž objevuje v ustanovení o obezřetných investicích při správě cizího majetku ( $§ 1432$ NOZ).

$110 \mathrm{~V}$ podobě nepeněžních aktiv.

$111 \S 376$ ZISIF.

112 Viz $\$ 375$ ZISIF

113 Viz $§ 376$ odst. 1 ZISIF.

114 Viz \& 376 odst. 2 ZISIF.

115 Český zákonodárce nicméně nepřebral z právní úpravy fiducie v Québecu výslovné ustanovení o tom, že žádná z oprávněných osob nemá k vyčleněnému majetku jakákoliv věcná práva. (Srov. SVEJKOVSKÝ, J. - MAREK, R. a kol., c. d., s. 329-332, s. 346, s. 459-460). Komentářová literatura však o věcněprávním charakteru práva obmyšleného k majetku ve svěřenském fondu neuvažuje (viz SPÁČIL a kol., c. d., s. 1205).
} 
možné pouze přiznat určitá ,plnění“ $\mathrm{z}$ této majetkové podstaty, a to v podobě (a) ius fruendi a (b) ius adquirendi, resp. (c) poměrného podílu k předmětu práv dle (a) a (b).

Právo českého obmyšleného na plnění ze svěřenského fondu má charakter relativního práva vůči svěřenskému správci, ${ }^{116}$ od něhož je obmyšlený oprávněn př́slušné plnění požadovat. Postavení obmyšleného má patrně nicméně též (přinejmenším) kvazivěcnou povahu ${ }^{117} \mathrm{~s}$ účinky erga omnes (každý musí respektovat jeho ius fruendi a ius adquirendi $\mathrm{z}$ majetku svěřenského fondu). ${ }^{118}$ Ius fruendi a ius adquirendi odpovídají oprávnění, které je právním chováním ve smyslu dare svěřenského správce. Svěrenský správce je povinován dát (poskytnout, vydat) obmyšlenému (a) plody a užitky (nebo podíl na nich), resp. (b) část nebo celek majetkové podstaty svěřenského fondu.

Byt' obmyšlený nemá right in the trust a vztah $\mathrm{k}$ majetkové podstatě svěřenského fondu připodobnitelný $\mathrm{k}$ beneficial interest (tj. majetkový - dle equity vlastnický - podíl k majetku v trustu), který by se projevoval vlastnictvím určitého „podílu“ či ,,jednotky“, náleží mu určité (ekonomické) výhody plynoucí ze správy majetku ve svěřenském fondu. Ius fruendi se vztahuje př́mo k výnosové složce majetku ve svěřenském fondu. Ius adquirendi pak staví obmyšleného do postavení faktického vlastníka in spe části nebo celku majetkové podstaty svěřenského fondu.

\subsection{SROVNÁNÍ S PODÍLOVÝMI FONDY}

Právní vztah obmyšlených k majetkové podstatě svěřenského fondu je zákonem opticky nastaven podstatně jinak než u podílníků podílových fondů. Podílníci jsou formálně poměrnými vlastníky majetku v podílovém fondu podle hodnoty jimi vlastněných podílových listů. Obmyšlení naproti tomu k majetkové podstatě ani formálně vlastnické právo nemají. Podílníci jsou však natolik omezeni ve svých spoluvlastnických právech, že ta jsou spiše jen formální, ryze nominální.

Shodné znaky lze v návaznosti na to nalézt v postavení „správcư“ svěřenských a podílových fondů. Svěrenský správce, resp. obhospodařovatel totiž vykonávají vlastnická práva $\mathrm{k}$ majetku $\mathrm{v}$ těchto fondech. Obmyšleným, kteří vlastnické právo $\mathrm{k}$ majetkové podstatě svěřenského fondu nemají ani formálně, i podílníkủm, jež jsou naopak formálně vlastníky majetku v podílovém fondu, může náležet právo na výnosovou složku tohoto majetku, př́ípadně právo na vydání majetku při ukončení správy (ve fyzické podobě u svěřenských fondů či pouze $\mathrm{v}$ peněžní formě v př́ípadě podílových fondů). V tomto ohledu se již jeví být pozice obmyšlených svěřenských fondů a podílníků podílových fondů velmi podobná.

Jak obmyšleným, tak podílníkům totiž fakticky náleží pouze určité (ekonomické) výhody plynoucí ze správy fondovního majetku, s nímž nemohou nikterak disponovat. Tyto ekonomické výhody jsou přitom v podstatě identické. S podílovým listem může být spojeno zejména (i) právo na podíl na zisku a (ii) právo na likvidačním zůstatku. ${ }^{119}$

\footnotetext{
116 SVEJKOVSKÝ, J. - MAREK, R. a kol., c. d., s. 459-460; podobně též SPÁČIL a kol., c. d., s. 1205.

117 SVEJKOVSKÝ, J. - MAREK, R. a kol., c. d., s. 416, s. 481.

118 Nelze zde opomíjet systematické zařazení právní úpravy svěřenského fondu v hlavě druhé (věcná práva) a části třetí (absolutní majetková práva) občanského zákoníku.

$119 \S 120$ odst. 2 písm. a) ZISIF.
} 
To do určité míry připomíná svěřenské (a) ius fruendi (ziskem lze totiž rozumět určitý výnos) a (b) ius adquirendi (likvidační zůstatek odpovídá zpeněženému majetku po odečtení dluhů při likvidaci podílového fondu, tj. podílníkům se vydává pouze peněžní ekvivalent majetku podílového fondu).

Do budoucna proto může být zajímavé uvažovat po vzoru podílových listů o inkorporaci práv obmyšlených do cenného papíru. Takové cenné papíry, označitelné např. po vzoru angloamerických trust certificates ${ }^{120}$ jako „,svěřenské certifikáty“, by sice nebyly vyjádřením určité jednotky nebo podílu na svěřenském fondu (jako je tomu u unit trusts a podílových fondů), mohly by se však stát novým právním institutem prohlubujícím mobilitu majetkových práv, jenž by napomohl ještě většímu (teoretickému i aplikačnímu) rozvoji tuzemského svěřenského práva. Zvláště v prostředí svěřenských fondů jako fondů investičních by takový cenný papír byl více než př́nosný, nebot' v období uzavření rukopisu tohoto textu ${ }^{121}$ nejsou v České republice podle seznamu vedeného ČNB žádné investiční fondy mající právní formu svěřenského fondu. ${ }^{122}$

\section{ZÁVĚR}

Svěřenské fondy jsou novým právním institutem, na který už byla i zacílena jedna z novel občanského zákoníku. Tuzemský právní institut svěřenského fondu je spiše jen určitou inspirací angloamerickými trusty. Přestože je totiž základní personální schéma (zakladatel - settlor, svěřenský správce - trustee, obmyšlený - beneficiary) zachováno, česká právní úprava se především vyznačuje zvýšenými administrativněprávními nároky na zúčastněné osoby, což někdy v právní teorii vede k označování svěřenských fondů za kvaziprávnické osoby nebo jejich přirovnání $\mathrm{k}$ fundacím. Mnohem inspirativnějšś a příhodnější je ovšem vztažení svěřenských fondů k právní úpravě fondů podílových. Podílové fondy jsou totiž již delší dobu upraveny v českém právním řádu a jejich ideovým základem jsou právě angloamerické trusty a unit trusts.

Z dílčího srovnání obou fondovních struktur vyplývá závěr, že pokud jde o faktický rozsah práv obmyšlených a podílníkủ, je možné nalézt určité spojující prvky. Obmyšleným, kteří k majetkové podstatě svěřenského fondu nemají vlastnické právo ani formálně, i podílníkům, již jsou naopak formálně vlastníky majetku v podílovém fondu, může náležet právo na výnosovou složku tohoto majetku, př́ípadně právo na vydání majetku při ukončení správy (ve fyzické podobě u svěřenských fondů či pouze v peněžní formě v prípadě podílových fondů). Pro další teoretické zkoumání a rozvoj svěřenských fondů v aplikační praxi proto může být velmi nosné zaobírat se možnostmi inkorporace práv obmyšlených do cenného papíru, nebot' lze vysledovat jistou podobnost mezi majet-

\footnotetext{
${ }^{120} \mathrm{~K}$ tomuto pojmu blíže např.: RIZVI, S. A. R. - BACHA, O. I. - MIRAKHOR, A. Public Finance and Islamic Capital Markets: Theory and Application. Palgrave Macmillan, 2016, s. 51.

121 Prosinec 2018.

122 Tento seznam vede Česká národní banka podle $§ 597$ písm. c) a $§ 598$ ZISIF. Zmíněný nulový stav se vztahuje ke dni 1. 12. 2018. (Česká národní banka. Celkový přehled počtu subjektů ke dni 1. 12. 2018. In: cnb.cz [online]. 1. 12. 2018 [cit. 1. 12. 2018]. Dostupné z: https://apl.cnb.cz/apljerrsdad/JERRS.WEB24 .SUBJECTS_COUNTS? $\mathrm{p} \_$lang $=\mathrm{cz}$.)
} 
kovými právy obmyšleného a právy, která jsou (mohou být) zakotvena v podílových listech.

Z pohledu právní teorie se tak jeví být zajímavé zkoumat spojitosti právě mezi oběma trust-like instituty, které jsou v českém právu prítomny, byt' byly zakotveny zcela paralelně a nezávisle. Na závěr by proto bylo možné poznamenat, že zákonodárce možná poněkud zbytečně implantoval úpravu québecké fiducie namísto snazšího uzpůsobení $\mathrm{v}$ českém právu etablovaného a dobře známého podílového fondu pro potřeby svěřenského práva. Tím by bylo možné vyhnout se i některým teoreticko-právním nesrovnalostem, mezi které patří např. odosobněné vlastnictví svěřenského fondu, tedy vlastnické právo bez osoby vlastníka.

JUDr. Jakub Vojtěch

Právnická fakulta Univerzity Karlovy

vojtechj@prf.cuni.cz

ORCID 0000-0003-0636-8079 